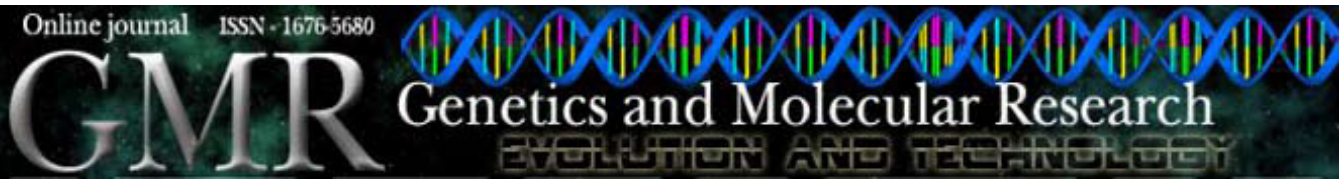

\title{
Antimutagenicity protection of Ginkgo biloba extract (Egb 761) against mitomycin $C$ and cyclophosphamide in mouse bone marrow
}

\author{
J.B. Vilar, K.R. Leite and L. Chen Chen \\ Departamento de Biologia Geral, Instituto de Ciências Biológicas, \\ Universidade Federal de Goiás, Goiânia, GO, Brasil \\ Corresponding author: L. Chen Chen \\ E-mail: chenleego@yahoo.com.br
}

Genet. Mol. Res. 8 (1): 328-333 (2009)

Received September 2, 2008

Accepted January 30, 2009

Published March 24, 2009

\begin{abstract}
Ginkgo biloba (Egb 761) extract, the most prescribed phytomedicine in Europe for the treatment of cerebral insufficiency and vascular diseases, was tested for its possible protective effects against mitomycin C (MMC)- and cyclophosphamide (CP)-induced mutagenicity using the micronucleus test in mouse bone marrow. The extract was co-administered to mice at doses of 50,100 and $200 \mathrm{mg} / \mathrm{kg}$ (po) with $4 \mathrm{mg} / \mathrm{kg}$ (ip) MMC or $24 \mathrm{mg} / \mathrm{kg}$ (ip) CP. All doses of Egb 761 were significantly $(\mathrm{P}<0.05)$ effective in reducing the frequency of micronucleated polychromatic erythrocytes, when compared with $\mathrm{MMC}$ or $\mathrm{CP}$ alone. Based on these results, we suggest that Egb 761 possesses both direct and indirect antimutagenic potential.
\end{abstract}

Key words: Ginkgo biloba; Egb 761; Antimutagenicity; Mitomycin C; Cyclophosphamide; Micronucleus test 


\section{INTRODUCTION}

The development of means to prevent cancer and other diseases related to the incidence of mutations, such as atherosclerosis, emphysema, cardiomyopathies, neurodegenerative diseases, are of enormous practical interest, primarily devoted to the detection of anti-risk factors for humans in a variety of test systems (De Flora and Ramel, 1988; De Flora, 1998; De Flora et al., 2001). Some studies in short-term tests have demonstrated that certain compounds are capable, at nontoxic concentrations, of lowering the rate of spontaneous or induced mutations (De Flora et al., 1994; Waters et al., 1996).

These substances are commonly found in plants and can act as natural antimutagens or anticarcinogens, blocking or scavenging the final electrophile moieties in a nucleophilic reaction, generating innocuous products; in this manner, the exposure to these substances would protect against DNA damage (Kaur et al., 2002). Due to the various roles plants can play, for centuries people have used them for healing. Plant products - as parts of food or botanical potions and powders - have been used with varying success to cure and prevent diseases, throughout history. Until recently, plants were an important source for the discovery of novel pharmacologically active compounds, with many blockbuster drugs being derived directly or indirectly from plants (Raskin et al., 2002).

Ginkgo biloba (Ginkgoaceae) is a native tree from China that has been exhaustively cultivated in Europe, Australia, Japan, Korea, and the USA, because of its health-promoting properties (Shinozuka et al., 2002). It has been used for 5000 years in traditional Chinese medicine. The standardized extract of this plant, called Ginkgo biloba extract - Egb 761 - was until recently the most prescribed phytomedicine in England and France, for the treatment of cerebral insufficiency and vascular diseases (Le Bars et al., 1997). In general, Egb 761 is composed of $24 \%$ flavonoids (glycoside derivates of quercetin, kaempferol, isohamentin and mycertin, in addition to some aglycone), $6 \%$ terpenoids (ginkgolides A, B, C, J, M, and bilobalides), and 0.5 to $1 \%$ organic acids (acetic, shikimic, p-hydroxybenzoic, vanillic, kynurinic, and ascorbic acids), besides other constituents (Goh and Barlow, 2002).

In view of the widespread use of Egb 761, the objective of the current study was to investigate the antimutagenic potential of multiple doses of Egb 761 on mouse bone marrow cells, to provide some clues about the preferential way of action that could occur when co-administered with mitomycin $\mathrm{C}(\mathrm{MMC})$, a direct-acting agent that does not require any molecular activation, or cyclophosphamide (CP), an indirect-acting agent, which needs to be converted enzymatically to its active metabolites.

\section{MATERIAL AND METHODS}

\section{Extract sample}

Commercially available Egb 761 was purchased at the "Farmácia-Escola" of the "Faculdade de Farmácia" of the Universidade Federal de Goiás.

\section{Chemical and drugs}

The chemical and drugs used in the experiment were the following: $\mathrm{MMC}\left(\mathrm{C}_{15} \mathrm{H}_{18} \mathrm{~N}_{4} \mathrm{O}_{5}\right.$; 
Bristol-Myers Squibb, Lot No. 217ACB), CP $\left(\mathrm{C}_{7} \mathrm{H}_{15} \mathrm{Cl}_{2} \mathrm{~N}_{2} \mathrm{O}_{2} \mathrm{P}\right.$; Sigma, Lot No. 87H0207), dibasic sodium phosphate $\left(\mathrm{Na}_{2} \mathrm{HPO}_{4} 12 \mathrm{H}_{2} \mathrm{O}\right.$; Merck, Lot No. 127H0168), monobasic sodium phosphate $\left(\mathrm{NaH}_{2} \mathrm{PO}_{4} \mathrm{H}_{2} \mathrm{O}\right.$; Merck, Lot No. 47H1445), Giemsa (Doles, Lot No. 1081), methanol ( $\mathrm{CH}_{4} \mathrm{O}$; Synth, Lot No. 39107), fetal bovine serum (Laborclin, Lot No. 30721063).

\section{Animals}

Healthy young adult (8-12 weeks) males of Mus musculus (Swiss Webster out bred mice), weighing 25-30 g, obtained from the Central Animal House of Universidade Federal de Goiás, were used in the studies. All animals were brought to the laboratory 5 days before the experiments. They were housed in plastic cages $(40 \times 30 \times 16 \mathrm{~cm})$ at $24 \pm 2{ }^{\circ} \mathrm{C}$ and $55 \pm$ $10 \%$ humidity, with a natural light-dark cycle of $12 \mathrm{~h}$. Food (appropriate commercial ration; Labina, Ecibra Ltda.) and water were provided ad libitum.

\section{Experimental procedure (micronucleus test)}

Five animal groups were co-treated by gavage with 50, 100, and $200 \mathrm{mg} / \mathrm{kg} \mathrm{Egb}$ 761 and $4 \mathrm{mg} / \mathrm{kg}$ MMC (ip) or $24 \mathrm{mg} / \mathrm{kg}$ CP (ip) (Salamone et al., 1980). The positive $(\mathrm{MMC}=4 \mathrm{mg} / \mathrm{kg}$ and $\mathrm{CP}=24 \mathrm{mg} / \mathrm{kg})$ and negative control groups $(0.1 \mathrm{~mL} / 10 \mathrm{~g}$ body weight sterilized distilled $\mathrm{H}_{2} \mathrm{O}$ ) were also included. After the periods of treatments $(36 \mathrm{~h}$ for MMC and $48 \mathrm{~h}$ for $\mathrm{CP}$ ), the animals were sacrificed. The femurs were exposed and cleaned, and the epiphysis sectioned. The bone marrow was gently flushed out using fetal bovine serum. After centrifugation (1500 rpm, $5 \mathrm{~min}$ ), bone marrow cells were smeared on glass slides, coded for blind analysis, air-dried and placed in absolute methanol for 5 min. The smears were stained with Giemsa for detecting micronucleated polychromatic erythrocytes (MNPCE) (Schmid, 1975). For each animal, three slides were prepared and 1000 polychromatic erythrocytes (PCE) were counted to determine the frequency of MNPCE. To determine the cytotoxicity of the plant extract, 1000 normochromatic erythrocytes (NCE) were counted, as well as the frequency of PCE within the same microscope fields. The PCE/NCE ratio was then calculated. The slides were analyzed using an Olympus BH-2 microscope (1000X).

\section{Statistical analysis}

The results of the antimutagenicity tests were tabulated and experimental values are reported as means \pm standard deviation. One-way independent sample ANOVA was used to detect differences between the doses of Egb 761 in the same co-treatment (MMC or CP). The Tukey post hoc test was then used when necessary. Pearson correlation was used to verify the association between the results obtained with both co-administrations. The percentage of inhibition (\%I) was measured by the complement of the rate between the average frequency of MNPCE of the test treatment and the average frequency of MNPCE of the positive control times $100(\% \mathrm{I}=1-(\mathrm{MNPCE}$ (Egb 761 and MMC or CP) / MNPCE (MMC or CP)) x 100). The cytotoxicity data were expressed as the PCE/NCE ratio, and the analyses were performed using the non-parametric Kruskal-Wallis test followed by the Mann-Whitney test, for the difference against positive controls. 


\section{RESULTS AND DISCUSSION}

The antimutagenic analyses are shown in Table 1. Our results demonstrate that Egb 761 was able to significantly protect $(\mathrm{P}<0.05)$ DNA from the mutagens studied when compared with each positive control (MMC or $\mathrm{CP}$ ), at all doses tested. The determination coefficient $\left(\mathrm{R}^{2}\right)$ between the two antimutagenic profiles was $53.29 \%(\mathrm{P}<0.0003)$.

\begin{tabular}{|c|c|c|c|c|}
\hline Treatment & Individual data MNPCE/1000 & Means \pm SD & $\% \mathrm{I}$ & $\mathrm{PCE} / \mathrm{NCE}$ \\
\hline $\mathrm{C}(-)$ : distilled $\mathrm{H}_{2} \mathrm{O}^{1}$ & $2-1-3-3-1$ & $2 \pm 1^{\mathrm{A}}$ & - & $0.99 \pm 0.254$ \\
\hline $\mathrm{C}(+): \mathrm{MMC} 4 \mathrm{mg} / \mathrm{kg}^{2}$ & $30-36-31-42-33$ & $34.4 \pm 4.8^{\mathrm{B}}$ & 0.00 & $0.49 \pm 0.110$ \\
\hline $50 \mathrm{mg} / \mathrm{kg} \mathrm{Egb} 761+4 \mathrm{mg} / \mathrm{kg} \mathrm{MMC}$ & $15-17-14-15-12$ & $14.6 \pm 1.81^{\mathrm{C}}$ & 57.56 & $0.56 \pm 0.06$ \\
\hline $100 \mathrm{mg} / \mathrm{kg}$ Egb $761+4 \mathrm{mg} / \mathrm{kg} \mathrm{MMC}$ & $14-16-17-18-18$ & $16.6 \pm 1.67^{\mathrm{C}}$ & 51.74 & $0.57 \pm 0.04$ \\
\hline $200 \mathrm{mg} / \mathrm{kg} \mathrm{Egb} 761+4 \mathrm{mg} / \mathrm{kg} \mathrm{MMC}$ & $16-18-19-15-16$ & $16.8 \pm 1.64^{\mathrm{C}}$ & 51.16 & $0.54 \pm 0.04$ \\
\hline $\mathrm{C}(+): \mathrm{CP} 24 \mathrm{mg} / \mathrm{kg}^{3}$ & $27-26-24-23-30$ & $26.0 \pm 2.74^{\mathrm{D}}$ & 0.00 & $0.42 \pm 0.09$ \\
\hline $50 \mathrm{mg} / \mathrm{kg} \mathrm{Egb} 761+24 \mathrm{mg} / \mathrm{kg} \mathrm{CP}$ & $16-17-15-15-18$ & $16.2 \pm 1.30^{\mathrm{E}}$ & 37.69 & $1.44 \pm 0.2 *$ \\
\hline $100 \mathrm{mg} / \mathrm{kg} \mathrm{Egb} 761+24 \mathrm{mg} / \mathrm{kg} \mathrm{CP}$ & $17-14-13-16-16$ & $15.2 \pm 1.64^{\mathrm{E}}$ & 41.54 & $1.28 \pm 0.11^{*}$ \\
\hline $200 \mathrm{mg} / \mathrm{kg} \mathrm{Egb} 761+24 \mathrm{mg} / \mathrm{kg} \mathrm{CP}$ & $7-6-9-7-8$ & $7.4 \pm 1.14^{\mathrm{F}}$ & 71.54 & $1.43 \pm 0.14^{*}$ \\
\hline
\end{tabular}

${ }^{1}$ Sterilized and distilled water (negative control group). ${ }^{2} \mathrm{MMC}\left(4 \mathrm{mg} / \mathrm{kg}\right.$ - positive control group). ${ }^{3} \mathrm{CP}(24 \mathrm{mg} /$ $\mathrm{kg}$ - positive control group). Values followed by the same letter do not present significant differences $(\mathrm{P}>0.05)$. *Significant difference $(\mathrm{P}<0.05)$ against its own positive control group.

In the light of these results, it is possible that common mechanisms of action of the extract, such as antioxidant activity, free radical scavenging and even gene regulation, could contribute to its direct and indirect antimutagenic profile. The use of MMC as an antitumor drug is due to its direct action on DNA. At least two different processes are responsible for its biological effects: DNA alkylation (which can lead to cross links) and the generation of free radicals, such as superoxide and hydroxy radicals (which can lead to DNA strand breaks) (Kang et al., 2006). On the other hand, the alkylating agent CP is one of a group of anticancer drugs that are administered as inactive prodrugs and that are activated in vivo via one or more metabolic steps. It is known that the initial step in the bioactivation of cyclophosphamide involves cytochrome P-450-mediated hydroxylation at C-4 (LeBlanc and Waxman, 1990).

Until now, the literature has demonstrated that Egb 761 has antioxidant properties, can act as a free radical scavenger and anti-inflammatory agent, can improve cognition, memory and anxiety, and can affect gene regulation (Gaudineau et al., 2004; Chen et al., 2005; Ergun et al., 2005; Krizková et al., 2008). It is also possible that direct interactions between the Egb 761 extract and these mutagens occur, since it has been pointed out that commonly used herbal medicines cause some herb-drug interactions (Izzo and Ernst, 2001; Williamson, 2001). Egb 761 itself has been reported to interact with some drugs, such as aspirin, acetaminophen or warfarin, provoking occurrences of cerebral and subarachnoid hemorrhage (Vaes and Chyka, 2000).

No significant difference $(\mathrm{P}>0.05)$ in the frequency of MNPCE was observed among the Egb 761 doses co-administrated with MMC and no significant difference $(\mathrm{P}>$ 0.05) was observed among the treatments and positive control PCE/NCE ratio (Table 1). The co-administration of Egb 761 and CP, on the other hand, revealed a significant increase in the PCE/NCE ratio and a significant difference $(\mathrm{P}<0.05)$ among the MNPCE frequen- 
cies (Table 1). The higher dose, $200 \mathrm{mg} / \mathrm{kg}$ Egb 761 and CP, caused a substantial augmentation of the \%I, compared with the doses of 50 and $100 \mathrm{mg} / \mathrm{kg}$. The $\% \mathrm{I}$ of the treatment with $200 \mathrm{mg} / \mathrm{kg}$ Egb 761 and MMC was 51.16\% and \%I of the treatment with $200 \mathrm{mg} / \mathrm{kg} \mathrm{Egb}$ 761 and CP was $71.54 \%$, which suggests that the standardized Ginkgo extract was more effective in the modulation of the mutagenic potential and cytotoxicity of the indirectacting drug CP. Despite the conflicting results obtained when the ability of the standardized Ginkgo extract or its constituents to modulate the cytochrome P-450 (CYP) was evaluated (Kuilman et al., 2000; Budzinski et al., 2000; Lautraite et al., 2002; Huynh and Teel, 2002), the effectiveness of the Egb 761 extract in the modulation of CP mutagenicity and cytotoxicity could be related to the inhibition of some CYP enzymes, which was demonstrated by Qualls et al. (1998). In this manner, changes in the level of expression of hepatic P-450s could affect the level of cyclophosphamide metabolism and, accordingly, its efficacy.

Other studies also support the antigenotoxic potential of Ginkgo biloba. Nunes (2004) observed its protective effect against doxorubicin (which can act as an intercalating antitumor drug or by the generation of reactive oxygen species) (Tewey et al., 1984) in $D$. melanogaster, and Krizková et al. (2008) related its antimutagenic action against ofloxacin and acridine orange in the flagellate E. gracilis. In conclusion, our results suggest for the first time that the standardized extract of this plant shows medicinal potential as an antimutagenic agent, modulating the mutagenicity caused by both direct- and indirect-acting chemical mutagens, in a mammalian model.

\title{
ACKNOWLEDGMENTS
}

\author{
Research supported by CNPq, FUNAPE and UFG.
}

\section{REFERENCES}

Budzinski JW, Foster BC, Vandenhoek S and Arnason JT (2000). An in vitro evaluation of human cytochrome P450 3A4 inhibition by selected commercial herbal extracts and tinctures. Phytomedicine 7: 273-282.

Chen B, Cai J, Song LS, Wang X, et al. (2005). Effects of Ginkgo biloba extract on cation currents in rat ventricular myocytes. Life Sci. 76: 1111-1121.

De Flora S (1998). Mechanisms of inhibitors of mutagenesis and carcinogenesis. Mutat. Res. 402: 151-158.

De Flora S and Ramel C (1988). Mechanisms of inhibitors of mutagenesis and carcinogenesis. Classification and overview. Mutat. Res. 202: 285-306.

De Flora S, Bennicelli C, Rovida A, Scatolini L, et al. (1994). Inhibition of the 'spontaneous' mutagenicity in Salmonella typhimurium TA102 and TA104. Mutat. Res. 307: 157-167.

De Flora S, Izzotti A, D’Agostini F, Balansky RM, et al. (2001). Multiple points of intervention in the prevention of cancer and other mutation-related diseases. Mutat. Res. 480-481: 9-22.

Ergun U, Yurtcu E and Ergun MA (2005). Protective effect of Ginkgo biloba against gossypol-induced apoptosis in human lymphocytes. Cell Biol. Int. 29: 717-720.

Gaudineau C, Beckerman R, Welbourn S and Auclair K (2004). Inhibition of human P450 enzymes by multiple constituents of the Ginkgo biloba extract. Biochem. Biophys. Res. Commun. 318: 1072-1078.

Goh LM and Barlow PJ (2002). Antioxidant capacity in Ginkgo biloba. Food Res. Int. 35: 815-820.

Huynh HT and Teel RW (2002). Effects of plant-derived phenols on rat liver cytochrome P450 2B1 activity. Anticancer Res. 22: 1699-1703.

Izzo AA and Ernst E (2001). Interactions between herbal medicines and prescribed drugs: a systematic review. Drugs 61: 2163-2175.

Kang YH, Lee KA, Ryu CJ, Lee HG, et al. (2006). Mitomycin C induces apoptosis via Fas/FasL dependent pathway and suppression of IL-18 in cervical carcinoma cells. Cancer Lett. 237: 33-44. 
Kaur S, Arora S, Kaur K and Kumar S (2002). The in vitro antimutagenic activity of Triphala - an Indian herbal drug. Food Chem. Toxicol. 40: 527-534.

Krizková L, Chovanova Z, Durackova Z and Krajcovic J (2008). Antimutagenic in vitro activity of plant polyphenols: Pycnogenol and Ginkgo biloba extract (EGb 761). Phytother. Res. 22: 384-388.

Kuilman ME, Maas RF and Fink-Gremmels J (2000). Cytochrome P450-mediated metabolism and cytotoxicity of aflatoxin $\mathrm{B}(1)$ in bovine hepatocytes. Toxicol. In Vitro 14: 321-327.

Lautraite S, Musonda AC, Doehmer J, Edwards GO, et al. (2002). Flavonoids inhibit genetic toxicity produced by carcinogens in cells expressing CYP1A2 and CYP1A1. Mutagenesis 17: 45-53.

Le Bars PL, Katz MM, Berman N, Itil TM, et al. (1997). A placebo-controlled, double-blind, randomized trial of an extract of Ginkgo biloba for dementia. North American EGb Study Group. JAMA 278: 1327-1332.

LeBlanc GA and Waxman DJ (1990). Mechanisms of cyclophosphamide action on hepatic P-450 expression. Cancer Res. 50: $5720-5726$.

Nunes WB (2004). Avaliação do Potencial Genotóxico e/ou Antigenotóxico do Extrato Egb 761 de Ginkgo biloba, em Células Somáticas de Drosophila melanogaster Tratadas com Doxorrubicina. Doctoral thesis, Universidade Federal de Uberlândia, Uberlândia.

Qualls CW Jr, Lubet RA, Lochmiller RL, Elangbam CS, et al. (1998). Cytochrome P450 induction in feral Cricetid rodents: a review of field and laboratory investigations. Comp. Biochem. Physiol. C. Pharmacol. Toxicol. Endocrinol. 121: 55-63.

Raskin I, Ribnicky DM, Komarnytsky S, Ilic N, et al. (2002). Plants and human health in the twenty-first century. Trends Biotechnol. 20: 522-531.

Salamone M, Heddle J, Stuart E and Katz M (1980). Towards an improved micronucleus test: studies on 3 model agents, mitomycin C, cyclophosphamide and dimethylbenzanthracene. Mutat. Res. 74: 347-356.

Schmid W (1975). The micronucleus test. Mutat. Res. 31: 9-15.

Shinozuka K, Umegaki K, Kubota Y, Tanaka N, et al. (2002). Feeding of Ginkgo biloba extract (GBE) enhances gene expression of hepatic cytochrome P-450 and attenuates the hypotensive effect of nicardipine in rats. Life Sci. 70: 2783-2792.

Tewey KM, Rowe TC, Yang L, Halligan BD, et al. (1984). Adriamycin-induced DNA damage mediated by mammalian DNA topoisomerase II. Science 226: 466-468.

Vaes LP and Chyka PA (2000). Interactions of warfarin with garlic, ginger, ginkgo, or ginseng: nature of the evidence. Ann. Pharmacother. 34: 1478-1482.

Waters MD, Stack HF, Jackson MA, Brockman HE, et al. (1996). Activity profiles of antimutagens: in vitro and in vivo data. Mutat. Res. 350: 109-129.

Williamson EM (2001). Synergy and other interactions in phytomedicines. Phytomedicine 8: 401-409. 